\title{
The Implementation of The Jakarta Smart City (JSC) Evi Satispi and Kurniasih Mufidayati
}

\author{
Magister of Public Administrative Science ; \\ The Faculty of Social and Political Sciences ; \\ Muhammadiyah Jakarta University \\ E-mail: \\ evi.satispi@umj.ac.id \\ kmf0219@gmail.com
}

\begin{abstract}
Jakarta wants to be an informative, transparent, and high technology city. The Jakarta Smart City (JSC) policy has been implemented since 2014, developing and improving public services in terms of information services more easily and better for citizen. At least there are eight applications that have already supported the implementation of JSC, such as the Qlue and Zomato JSC. Now, Implementation of the JSC in the state capital, Jakarta, still finds a number of challenges. Jakarta has not succeeded yet , getting the Indonesian Smart City Rating (RKCI) at the end of 2017. The problem of this research is to answer "How is Jakarta Smart City (JSC) Policy Implementation in Jakarta?" This study uses a qualitative approach and descriptive method. A number of JSC stakeholders were interviewed in depth as informants, both from JSC managers and the community as users. The study was conducted on a number of Smart City applications in Jakarta and Surabaa. The theories of Colldahl (2013) and Griffinger (2007) about Smart City used as the foundations and theory framework of this research. This concept explained the Six Smart City Characteritics for analyze the JSC implementation in Jakarta. The results of this research showed that Jakarta, respectively, already have many programs and applications for the those Six characteristics of Smart City. Jakarta has just implemented smart city in 2014. Jakarta has succeeded getting Smart City awards from many institutions and foundations.
\end{abstract}

\section{Keywords : Smart City, Jakarta Smart City, Implementation}

\section{PRELIMINARY}

The growth of urban population both naturally and migration, from year to year raises the challenges of increasingly complex city management. Cities have the dynamics of rapid change. The impact of this population growth is increasingly crowded road traffic, increasingly heavy pollution, narrowed parking lots, stuffy air, greater use of electrical energy etc. City development and construction needs continue to grow, especially in various aspects of public services and spatial planning and living facilities. Meanwhile, the city has many limited resources that support the fulfillment of these needs. Half of the world's population is currently residing in cities, and it is expected that this number will rise to $70 \%$ by 2050 (UN World Urbanization Prospects ; 2011 in Colldahl ; 2013)

Cities face increasingly large and complex challenges in providing facilities and various public services to their citizens. Governance of cities should be able to meet basic needs such as health, education, public transport, so that citizens feel the security, comfort, and happiness. This condition requires the Regional Government to be able to maximize the potential of its resources and minimize the obstacles or problems faced. Therefore city management is needed through a better urban governance approach, comprehensive city maintenance, and smart city design where conditions and productivity of the population are well maintained. 
Responding to the complexity of these big challenges, Smart City has become a big issue for big cities in the world as an alternative solution for better city management. New York, Tokyo, London, Chocago, Singapore, Seoul and other major cities have implemented Smart City with a citizen centric approach and based on the use of resources and technology so that there is synergy in the management of a more dynamic and positive city between all resources and technology. Berger Roland (2017) said that based on the Smart City Strategy Index there are 87 global cities in the world that have used Smart City in overcoming the dynamics of managing big cities. Vienna, Chicago and Singapore are the 3 best cities in implementing Smart City. Learning from these cities, Smart City optimizes its resources and is supported by the use of technology to facilitate city residents to enjoy public facilities and services quickly and accurately. This synergy continues to grow and to proceed so as to create a comfortable city and faster in responding to changes and new challenges that come up in these cities.

This reality is also faced by capital city of Indonesia, namely Jakarta. Prof. Dr. Suhono Harso Supangkat from the Bandung Institute of Technology (ITB) said that there were no regions in Indonesia that really have achieved perfect scores as smart cities. All major cities that implemented Smart City were said to have only directed to smart city (https://properti.kompas.com/ read / 2016/09/22/182433821 / no smart city in Indonesia). Jakarta has dynamic characteristics of large cities with high population density, multi ethnicity and high speed of service demands. According to BPS report on 2017, Jakarta with an area of about $661.52 \mathrm{~km}^{2}$ (sea: $6,977,5 \mathrm{~km}^{2}$ ) has a population of 10.37 million people. Jakarta has adopted the Smart City Concept in city management since 2014. How is the Smart City implemented in Jakarta? This research was conducted to answer that research question.

\section{LITERATURE REVIEW}

Many smart city definitions are developed from experts as follow. (PSSR UGM; Working Paper : 2016) :

\begin{tabular}{|l|l|l|}
\hline Num & Experts & Definition \\
\hline 1 & Yang (2012) & $\begin{array}{l}\text { Urban that creats a sustainable economic } \\
\text { development and high quality of life for its citizens } \\
\text { by increasing 6 main things (governance, economy, } \\
\text { quality of life, environment, human resources and } \\
\text { transportation) that can be done with a strong } \\
\text { information and communication technology } \\
\text { infrastructure }\end{array}$ \\
\hline 2 & $\begin{array}{l}\text { A city well performance in a foreard-looking way in } \\
\text { these six characteristics (economy, people, } \\
\text { governance, mobility, environment and living) built } \\
\text { activities of self-decisive independent and aware } \\
\text { citizens }\end{array}$ \\
\hline 3 & $\begin{array}{l}\text { Acity that monitors and integrates conditions of all } \\
\text { of its critical infrastructures, including roads, } \\
\text { bridges, tunnels, rails, subways, airports, seaports, } \\
\text { communications, water, power, even major } \\
\text { buildings, can be better optimize its resources, plan } \\
\text { its preventive maintenance activities and monitor } \\
\text { security aspects while maximizing services to its } \\
\text { citizens }\end{array}$ \\
\hline
\end{tabular}

Griffinger et al (2007) explained that the concept of smart city has 6 (six) dimensions 
as the basis for the application of smart city has been used to calculate the smart city index in 70 (seventy) cities in Europe. The six dimensions and each parameter can be seen in the following figure:

\begin{tabular}{|c|c|}
\hline $\begin{array}{l}\text { SMART ECONOMY } \\
\text { (Competitiveness) }\end{array}$ & $\begin{array}{l}\text { SMART PEOPLE } \\
\text { (Social and Human Capital) }\end{array}$ \\
\hline $\begin{array}{l}\text { - Innovative spirit } \\
\text { Entrepreneurship } \\
\text { - Economic image \& trademarks } \\
\text { - Flexibility of labour market } \\
\text { - International embeddedness } \\
\text { Ability to transform }\end{array}$ & $\begin{array}{l}\text { - Level of qualification } \\
\text { - Affinity to life long learning } \\
\text { - Social and ethnic plurality } \\
\text { - Creability } \\
\text { - Cosmopolitanism/Open- } \\
\text { mindedness } \\
\text { - Participation in public life }\end{array}$ \\
\hline $\begin{array}{l}\text { SMART GOVERNANCE } \\
\text { (Participation) }\end{array}$ & $\begin{array}{l}\text { SMART MOBILITY } \\
\text { (Transport and ICT) }\end{array}$ \\
\hline $\begin{array}{l}\text { - Participation in decision-making } \\
\text { - Public and social services } \\
\text { - Transparent governance } \\
\text { - Political strategies \& perspec- } \\
\text { tives }\end{array}$ & $\begin{array}{l}\text { - Local accessibility } \\
\text { - (Inter-)national accessibility } \\
\text { - Availability of ICT-infrastructure } \\
\text { Sustainable, innovative and safe } \\
\text { transport systems }\end{array}$ \\
\hline $\begin{array}{l}\text { SMART ENVIRONMENT } \\
\text { (Natural resources) }\end{array}$ & $\begin{array}{l}\text { SMART LIVING } \\
\text { (Quality of life) }\end{array}$ \\
\hline $\begin{array}{l}\text { - Attractivity of natural conditions } \\
\text { - Pollution } \\
\text { - Environmental protection } \\
\text { - Sustainable resource manage- } \\
\text { ment }\end{array}$ & $\begin{array}{l}\text { - } \text { Cultural facilities } \\
\text { - Health conditions } \\
\text { - Hndividual safety } \\
\text { - Housing quality } \\
\text { - } \text { Education facilities } \\
\text { - Souristic attractivity } \\
\text { - Social cohesion }\end{array}$ \\
\hline
\end{tabular}

Smart City Dimensions (Giffinger, et al; 2017)

According to Colldahl (2013), there are 6 dimensions of smart city as follows :

1. Smart Economy refers to a city's overall competitiveness, based on its innovative approach to business, research and development (R\&D) expenditures, entrepreneurship opportunities, productivity and flexibility of the labour markets, and the economical role of the city in the national and international market.

2. Smart People means delivering a high and consistent level of education to the citizens, and also describes the quality of social interactions, cultural awareness, openmindedness and the level of participation that citizens hold in their interactions with the public life.

3. Smart Governance more specifically addresses participation at a municipal level. The governance system is transparent and allows for citizens to partake in decision-making. ICT infrastructure makes it easy for citizens to access information and data concerning the management of their city. By creating a more efficient and interconnected governance system, barriers related to communication and collaboration can be eliminated.

4. Smart Mobility advocates more efficient transportation systems (e.g. non-motorised options) and promotes new social attitudes towards vehicle usage, ensuring that citizens have access to local and public transportation, and that ICT again is integrated to 
increase efficiency. Smart cities seek to increase how efficiently people, goods, and vehicles are transported in an urban environment.

5. Smart Environment emphasises the need for responsible resource management and sustainable urban planning. Through pollution and emission reductions, and efforts towards environmental protection, the natural beauty of the city can be enhanced. Smart cities promote the reduction of energy consumption, and the integration of new technological innovations that result in efficiency gains.

6. Smart Living seeks to enhance the quality of life of citizens, and does so by providing healthy and safe living conditions. Citizens in smart cities have easy access to health care services, electronic health management, and to diverse social services.

From some literature above, Smart City can be interpreted as a city that uses information technology to integrate all infrastructure and services from the government to the public, such as administration, education, health, transportation, economy, energy resources, housing and public safety so that all aspects can be synergy together with the community will be able to improve the development and management of the city.

\section{RESEARCH METHODS}

The study used a qualitative approach and descritive method. Primary data collected by interviewing many related stakeholders in administrative cities in Jakarta ; South Jakarta, North Jakarta, West Jakarta and East Jakarta. Those stakeholders were the city government and related agencies such as the Office of Communication and Information (Diskominfo), City Planning and Landscaping Service, companies that collaborated with the government in implementing technology, academics who had attention to the issue of smart cities, NonGovernmental Organizations and, of course, some people who are actively involved in smart city programs. Direct observation and analizing some documents refers to Smart City implementation in Jakarta has been done, too.

Field research was carried out for 3 months in Jakarta and Surabaya on Januari - March, 2018. During the fieldwork, research recorded every event and activity observed, and used recording tools for interviews and cameras for documentation.

\section{RESEARCH RESULTS}

\section{The Jakarta Smart City (JSC) Implementation in Jakarta}

Jakarta Smart City (JSC) has established since 2015. Jakarta Smart City (JSC) is a management unit under the Jakarta Provincial Government - has been tasked with realising smart city vision. It strives for a more data-driven, transparent and collaborative use of technology to ensure better public services for residents in the capital. Similar to Surabaya, in accordance with the Smart City concept from Griffinger et al (2007) and Colldahl (2013), Jakarta Smart City was developed in 6 dimensions. The JSC translates the 6 dimensions as follows.

Jakarta Smart City (JSC) has been established since 2015. Jakarta Smart City (JSC) is a management unit under the Jakarta Provincial Government - has been tasked with realizing smart city vision. It strives for more data-driven, transparent and collaborative use of technology to ensure better public services for residents in the capital. Similar to Surabaya, in accordance with the Smart City concept from Griffinger et al (2007) and Colldahl (2013), Jakarta Smart City was developed in 6 dimensions. The JSC translates the 6 dimensions as follows. 


\section{Smart Governance; transparent, informative and responsive government}

Smart Governance in Jakarta is carried out through the e-Government policy.Open Data in planning and budgeting. The Open Data system services are carried out to encourage integrated and transparent public services. The planning system is also supported by technology systems such as data portals, various complaint applications. There are 180 applications both financial clusters, as well as population clusters. The development policy for internal governance is directed to the intranet model while the community service is directed to the internet model.

Many Smart Governance programs have been implemented, including:

a) E-Budgeting as a means of regional financial management from the stage of the budget planning process

b) E-musrenbang as a means of public consultation in the development plan

c) JAKARTA SATU Policy with the concept of ONE DATA, ONE MAP, ONE POLICY aims to share data using multiple applications

d) Qlue as a complaints system that can be used by the public and the government in providing public servants effectively and cutting the bureaucratic time for complaints services. Qlue is an application that is integrated with Jakarta Smart City in the form of social media for reporting complaints and appreciation of the surrounding environment through the link http://www.qlue.co.id. Community Reports through Qlue include Congestion, Violations, Damaged Street Lights, Garbage, Damaged Roads, Fasum, Illegal Parking, Beggars, Wild Walkers, criminals, floods, fires, terrorism and building permit violations and other complaints

e) Report! has designed for handling reports, request and complaints. Every report that comes to Report! is channeled directly to Public Opinion Response (ROP) as the main public report tools.

f) Online One Stop Services (PTSP) provides integrated services online for many types of services.

g) Jakarta Smart City portal

h) Citizen Relationship Management

Jakarta Smart City is displayed in real time conditions of congestion, flood predictions, ambulances, fire engines, as well as population and health services carried out in DKI Jakarta Provincial

2. Smart Environment; eco-friendly natural resource management Some Smart Environment programs include:

a) The Green Building Certification aims to assess building ratings towards the achievement of the concept of environmentally friendly buildings. There are more than 15 certified buildings.

b) Air quality monitoring in Jakarta has around 11 air quality monitoring devices located at several points, including around Sudirman and Gambir roads

c) Public Street Lighting (PJU) Smart using Public Street Smart System Information is an application of IoT or Internet of Things. Light Emitting Diode Smart System (LED SS) has been installed in various places in Jakarta to implement Smart System Public Street Lighting (PJU). There are tens of thousands of Smart PJU in Jakarta

d) The Grebek Trotoar plan was launched to welcome ASEAN Games. This program is in the form of sidewalk revitalization so the clean and comfortable sidewalks can be created 


\section{Smart People (improving the quality of human resources and living facilities properly)}

Smart People has a well educated human capital indicator both formally and non-formally and is realized in creative individuals or communities. The Smart People program includes:

a) The Jakarta Pintar Card (KJP) Plus is a card that provides access for DKI Jakarta citizens from the community who are unable to get a minimum education until graduating from high school / vocational high school and helping the college. This card is also used for study groups packages $\mathrm{A}, \mathrm{B}$, and $\mathrm{C}$, madrasa education, Islamic boarding schools and skills courses.

b) IJakarta provides digital library application facilities offered by the DKI Library and Archives Service. With Jakarta, people can borrow free books.

c) Jakarta One Card is a smart card that functions as an e-KTP, shopping payment instrument, and BPJS

d) Jakarta Smart City Edutrip so that public insight about Smart City will increase so that later all can participate to realize the smart city of Jakarta. Jakarta Smart City Edutrip is open to citizens of Jakarta and outside Jakarta, even open to foreign nationals. Schools, campuses, or communities can also visit JSC Lounge collectively through this program

\section{Smart Mobility; provision of transportation and infrastructure systems}

a. TRAFI Has been designed to make mobility services the first choice worldwide. It helps the public transportation, map, etc. Using the link https://www.trafi.com/id/jakarta

b. In collaboration with Transjakarta and TRAFI to analyze patterns of use of public transportation that are useful for the development of policy and urban planning.

c. Transjakarta Monitoring Application and Electronic Parking

d. Waze, an application that can search routes, guide, in real-time via the link http://www.waze.com

e. The upcoming 2019 Mass Rapid Transit or MRT and LRT operation plan. It is also planned that the MRT-J application can be downloaded in Playstore and Appstore. When entering the main dashboard, there are three main menus in the MRT-J application, namely to the Station, Travel and Roaming Station.

\section{Smart Living; realize a healthy and livable city}

Smart Living is present to meet the quality of life and culture of the factor community, including the availability of needs, the security, safety, convenience and comfort of life through the Flood Monitoring System, CCTV Integration and Integrated Flats. There are around 5,000 CCTV cameras in Jakarta that are integrated with the Jakarta Smart City system which will be developed in the City Surveillance System program. To provide other conveniences for the community, Smart Living also presents, among others:

a. Zomato, the restaurant search application, provides in-depth information for more than one million restaurants in 22 countries. https://www.zomato.com/indonesia

b. Ragunan Zoo, Application contains information about all Ragunan Wildlife Park activities and facilities. http://ragunanzoo.jakarta.go.id

c. Go-Food, Indonesia's number one online food delivery service with around one million active users every month and ten million orders during 2015. http://www.go-food.co.id/ 
d. Food Information Jakarta, Information container for current food prices, price increases and price comparison between markets in Jakarta.

http://infopangan.jakarta.go.id/

In order to improve the ease and speed of communication and information services and a more modern digital life, Jakarta Smart City plans to build a network model using optical fiber and $5 \mathrm{ghz}$ wireless. Plans The presence of a new breakthrough $5 \mathrm{G}$ connection that is capable of sending data up to $20 \mathrm{Gbps}$, latency or low service time lag ( $<=1 \mathrm{~ms}$ end to end latency), and can be used around 2000 people at the same time. In addition, WiGig technology will also be present which can provide home connections of up to $1 \mathrm{Gbps}$, wide coverage areas, and relatively easy installation processes.

\section{Smart Economy; growing productivity with entrepreneurship and the spirit of innovation}

Smart Economy is shown by the high level of economy and financial well-being of the people with good economic growth and high per capita income through the legacy program, Jakarta Food Information and Jakarta One. On the smart economy aspect, collaboration is carried out with Tokopedia and Zomato with a focus on the MSME sector in Indonesia. Ragunan Zoo, Go Food and Info Pangan are also designed to develop Smart Economy in Jakarta.

Digitizing Micro, Small and Medium Enterprises (MSMEs) is one of the ways taken by DKI Jakarta Provincial Government to facilitate Jakarta entrepreneurs. This effort is supported by a program called JAKmikro. There are three main components of JAKmikro, namely microBina, mikroPay, and mikroApps. JSC Hive Coworking Space has been created as Smart Economy programs. It connects startups with local governments to simplify business processes for beginners. It will provide a decent and modern work space at affordable prices for digital workers.

All forms of the Jakarta Smart City program are hosted through the Jakarta Smart City Portal with the link https://smartcity.jakarta.go.id/. The smartcity.jakarta.go.id information portal is accessed by around $70 \%$ of users using mobile devices. This proves that the Jakarta Smart City product is important for residents and easily accessible through various devices, including through smartphones. The most popular data accessed is online CCTV that displays current conditions in thousands of points from all over Jakarta. Jakarta Smart City also has its own space as a control center in the smart city operation called Smart City Lounge.

Seeing the many programs and activities in the 6 Smart City dimensions above, the city of Jakarta is very fast in developing the Smart City concept. A number of achievements related to the development of Smart City have been achieved by Jakarta, including:

1. Become one of the Asean Smart Cities Governance models

The DKI Jakarta Provincial Government (Pemprov) is appointed as one of the chief smart city officers for the Association of Southeast Asian Nations (ASEAN) Smart Cities Network in the Smart Cities Governance Workshop (SCGW) in Singapore on 22-25 May 2018. SCGW is a continuation of the Conference The 32nd ASEAN Summit

2. Appreciation of 2017 technology-based smart city governance from the Ministry of Home Affairs. 2016 GovInsider Innovation Awards Best Team Under 35 for 
Local Government JSC management units that are ready to implement Smart City Nusantara

3. The DKI Provincial Government has received an award for the implementation of smart city and e-government in the event the 4th World e-Governments Organization of Cities and Local Governments (WeGO) of the Smart Sustainable City Awards, held July 3-30, 2017 in Ulyanovsk, Russia

\section{CONCLUSION}

The development of Jakarta Smart City in general has already covered six dimensions proposed by Griffinger (2007) and Colldahl (2013), namely smart economy, smart people, smart governance, smart mobility, smart environment, and smart living. All administrative cities in Jakarta gradually has applied Smart City Concept, adjusted to the conditions of the city at that time (for example: priority issues, community readiness, budget). The Jakarta Smart City (JSC) has implemented since 2014. It developed very fast, because Jakarta must quickly respond to the capital city needs and movements. Many technological-based advances were quickly developed in Jakarta. This is because of the budget potential in Jakarta for The Jakarta Smart City programs are quite large.

In terms of the theory or concept used in this study it can be concluded that the findings in this study support the theory or concept of Smart City Dimensions according to Griffinger (2007) and Colldahl (2013), namely smart economy, smart people, smart governance, smart mobility, smart environment, and smart living. However, not all parameters of each dimension can be fulfilled by Jakarta, as evidenced by the existence of problems that occur such as floods, congestion, environmental pollution, unemployment, and other problems. All components involved in smart city must always include people, process, and technology

\section{REFERENCE}

Batty, Michael, et.al. 2012. Smart Cities of the Future. Working Paper Series, Paper 188-Oct 12. University College London.

Chourabi, Hafedh, et.al. 2012. Understanding Smart Cities: An Integrative Framework. 45th Hawaii International Conference on System Sciences. IEEE Computer Society. Page 2298-2297.

Colldahl, C., \& Kelemen, J. E., "Smart Cities : Strategic Sustainable Development for an Urban World," 2013.

Cohen, B, 2012. The top 10 smart cities on the planet. https://www.fastcodesign.com/1679127/the-top-10-smart-cities-on-the-planet. Diakses 24 April 2016.

Cohen, B, 2014. The smartest cities in the world 2015. https://www.fastcompany.com/3038818/the- smartest-cities-in-the-world2015-methodology. Diakses 24 April 2016.

Griffinger, R., dkk (2007). Smart cities Ranking of European medium-sized cities. Final report October.

Hall, Robert E, et.al. 2000. The Vision of A Smart City. Presented at the 2nd International Life Extension Technology Workshop Paris, France. 